\section{Life and Work of William Henry Perkin}

THE special honour and affection in which the late 1 Prof. W. H. Perkin was held by the Chemical Society is reflected in the publication of a special number of the Society's Journal (price 3s. 6d.) giving an account of the life and work of "this great master in organic chemistry". Prof. Perkin, who was Longstaff medallist, first Pedler lecturer, and a past president of the Society, and had been most closely associated with the development of chemical studies and knowledge in the Universities of Manchester and Oxford, died on Sept. 17, 1929.

The story of Perkin's life from the personal point of view has been written by Mr. A. J. Greenaway, a lifelong friend, and formerly editor of the Society's Journal, in which the results of most of his researches were published. His scientific work has been described by two of his old associates, Prof. J. F. Thorpe, who confines himself to the Würzburg, Munich, Edinburgh, and Manchester periods, 1880-1912, and Prof. R. Robinson, who discusses a selection of the subjects in the study of which Perkin was actively engaged: the constitution of berberine; brazilin and hæmatoxylin ; harmine and harmaline; cryptopine and protopine. There is appended a bibliography of 271 papers published by Perkin and his collaborators; there are four posthumous papers on strychnine and brucine yet to be published. The book also includes three photographs of Perkin, and one of the memorial plaque presented in triplicate to the Society and the Universities of Manchester and Oxford by his colleagues and pupils.

William Henry Perkin was born on June 17, 1860 ; he was first sent to preparatory schools at Harrow, and later to the City of London School, chosen by his father, Sir William Perkin, founder of the coal-tar dye industry, not merely because it was his old school, but also because it was then "the only one he could find where science was taught". The science master was Henry Durham, who gave courses in chemistry, botany, and physiology alternately, and there was a practical chemistry class on Saturday afternoons, when the boys worked at the lecture table. In the garden of his father's house at Sudbury there was a hut fitted as a laboratory where the Perkin boys, W. H. and A. G., were brought up in an atmosphere of research but without systematic instruction. In 1877, Perkin entered the Royal College of Chemistry at South Kensington and studied under Prof. (later Sir Edward) Frankland and Dr. W. R. E. Hodgkinson; in 1880 he went to Würzburg, studying chemistry under Wislicenus, physics under Kohlrausch, and mineralogy under Sandberger, and in 1882 he went to Munich to work under Baeyer. Here he established a claim to be regarded as one of the most promising of the younger chemists.

In 1887, Perkin was appointed the first professor of chemistry at the newly founded Heriot-Watt College at Edinburgh; his work on ring compounds was continued, much work on other subjects, including camphor, was undertaken, and the alkaloid investigations were commenced. The University of Manchester secured him in 1892; he then entered on what he once described as his 'golden age' of research, and his school established a world-wide reputation. Tempting offers of chairs elsewhere were refused, but in 1912, Perkin accepted the Waynflete professorship of chemistry at Oxford and a fellowship of Magdalen College. At Oxford he completely transformed the chemistry school, liberating a flood of new knowledge. Admirers of the man himself, genial and warmhearted, and of his immense services to organic chemistry, will prize this triple tribute to his memory.

\section{University and Educational Intelligence}

CAmbridge.-Dr. A. G. Hutchison, of Emmanuel College, has been appointed University demonstrator in mineralogy and petrology.

Dr. R. S. Hutton, director of the British NonFerrous Metals Research Association, has been ap. pointed the first Goldsmiths professor of metallurgy. Dr. Hutton, who was educated at Blundell's School, Tiverton, Owens College, Manchester, and the Universities of Leipzig and Paris, was lecturer in electrometallurgy in the University of Manchester in 1900-8.

Applications are invited by the University of Wales for five fellowships, each of the annual value of $£ 200$ and tenable for two years. The fellowships are open only to graduates of the University of Wales. Applications must reach the Registrar, University Registry, Cathays Park, Cardiff, by at latest June 1.

SCHOLARSHIPs for the encouragement of original research in sanitary science are again being offered by the Grocers Company. The value of each is $£ 300$ a year, plus an allowance for expenses in connexion with the work undertaken. Applications, upon a form supplied on request, must be received before the end of April by the Clerk to the Grocers Company, Grocers Hall, E.C.2.

The Board of Education announces that it is prepared to consider applications for full-time studentships from teachers with at least five years' teaching experience who desire financial assistance to follow courses of advanced study at universities or other institutions at home or abroad. Particulars of the awards and application forms are obtainable from the Board of Education, Whitehall, S.W.1.

Mexico's Department of Education offers to a world, wrestling to balance its budgets, a signal example of how to achieve equal or better schooling with less outlay. In that country, it appears, rural schools are based on the idea of building up the community economically, socially, and spiritually, and there is consequently a prejudice against residential schools as alienating children from their home surroundings. However, an exception was allowed in the case of Indians afflicted with a certain disfiguring but evidently not disabling disease (mal del pinta), and a party of thirty-five, ranging in age from ten to eighteen years, was assembled last April on a forty-acre site at San Gabrielito and set to work to make a residential school. Arriving with nothing but a blanket each and the clothes they stood up in, they were made to construct for themselves, sleeping the while on the bare ground, with clay and timber found on the spot, a sufficient and attractive building with necessary furniture, and to make shoes, belts, hats, chairs, and other articles for sale to obtain the wherewithal to buy such clothing as they needed and could not make, and instruments for a school orchestra. Within three months, the school was in successful operation. These facts are recorded in an article contributed by Mrs. Cook, chief of the special problems division of the Office of Education, Washington, to the October number of School Life. The same number contains a significant excerpt from an address by the Secretary of the Interior, the general drift of which is summed up in the following words: "Never was there a time when studies and experiments in the vocational training of our youth were more necessary than to-day. . . We must not let the fetish of cultural education interfere with an up-to-date and effective training of our children." 